\title{
Microbial invasions in terrestrial ecosystems
}

\author{
Madhav P. Thakur $\mathbb{0}^{1 *}$, Wim H. van der Putten ${ }^{1,2}$, Marleen M. P. Cobben ${ }^{1,3}$, \\ Mark van Kleunen ${ }^{4,5}$ and Stefan Geisen (1) ${ }^{1}$
}

\begin{abstract}
Human travel and global trade have tremendously increased the spread of invasive microorganisms in new regions. Experimental and observational studies in terrestrial ecosystems are beginning to shed light on processes of microbial invasions, their ecological impacts and implications for ecosystem functioning. We provide examples of terrestrial invasive microorganisms, including bacteria, fungi, oomycetes and other protists, and viruses, and discuss the impacts of pathogenic and non-pathogenic invasive microorganisms at levels ranging from host species to ecosystems. This Review highlights that despite the recent progress in microbial invasion research, we are only beginning to understand how alien microorganisms interact with native microorganisms, and the implications of those interactions. Finally, we propose three research themes - microbial interactions, impacts and climate change - to make microbial invasion research a truly integrative discipline.
\end{abstract}

Introduction

The second stage in the invasion process, when the alien species arrives in the new environment (including being kept in captivity or cultivation).

${ }^{1}$ Department of Terrestrial Ecology, Netherlands Institute of Ecology (NIOO-KNAW), Wageningen, The Netherlands.

${ }^{2}$ Laboratory of Nematology, Wageningen University, Wageningen, The Netherlands.

${ }^{3}$ Theoretical Evolutionary Ecology Group, Würzburg University, Würzburg Germany.

${ }^{4}$ Ecology Group, Department of Biology, University of Konstanz, Konstanz, Germany.

${ }^{5}$ Zhejiang Provincial Key Laboratory of Plant Evolutionary Ecology and Conservation, Taizhou University, Taizhou, China

${ }^{*} e$-mail:

m.thakur@nioo.knaw.nı
Microorganisms are migrating at unprecedented levels owing to ever-increasing global trade $\mathrm{e}^{1,2}$, human travel $\mathrm{l}^{3,4}$ and forced migration of plants and animals owing to anthropogenic climate change ${ }^{5,6}$. Successful invasion of alien microorganisms in the new environments can have dramatic effects on their hosts and recipient ecosystems $^{7-9}$, as exemplified by several Phytophthora species that kill a range of plant species ${ }^{10}$ (FIG. 1; TABLE 1) or by the chytrid fungus Batrachochytrium dendrobatidis, which causes global amphibian declines ${ }^{11}$ (examples of other systems are given in BOX 1). Yet, information on alien microorganisms that have become invasive and their subsequent impacts on ecosystems remains scattered, and an integrative understanding of the microbial invasion process, the impacts of alien microorganisms on native species and communities, and implications for ecosystem functioning is lacking.

Understanding the invasion process and transitions between the different stages from the introduction of an alien species in a new environment to its population outbreak and subsequent spread ${ }^{12,13}$ is central in invasion biology research. A key challenge in invasion biology has been to define what an alien species is. The two criteria that have received wide consensus are a species introduced into a new biogeographic range and through human agency ${ }^{14}$. In the absence of human agency, if a species disperses to a new environment or expands its biogeographic range autonomously, the species would not be defined as alien. Indeed, species migration outside its geographic range owing to anthropogenic climate change can be considered an indirect human-mediated species introduction (BOX 2). However, in this Review we consider a species alien only when it is directly introduced by human activities outside its known biogeographic boundaries, following the definition used in invasion research of other organisms, such as animals and plants. Further, according to the Convention on Biological Diversity ${ }^{15}$, an alien species is invasive only if it threatens the native biodiversity of recipient ecosystems and negatively affects ecosystem functions, which could lead to detrimental socioeconomic impacts. A more neutral definition, independent of impact, is when an alien species reaches the spread stage, which is typically but not necessarily the stage at which the population of the alien species becomes disproportionately larger than its known abundance in its native range $\mathrm{e}^{12,16}$.

Ecological impacts of alien microorganisms usually become apparent when they reach the spread stage (FICS 1,2). In contrast to macroorganisms, most alien microorganisms remain undetected given the lack of their visible impacts on hosts and recipient ecosystems ${ }^{17}$. Hence, both the detectability and the negative impact, at least on native species, communities or ecosystems, are two central characteristics for an alien microorganism to be called 'invasive.' Accordingly, we define an invasive microorganism (viruses, bacteria, archaea, protists and fungi) in this Review as alien when it has reached the spread stage (and is detectable) and alters the dynamics of host and non-host species leading to losses in biodiversity and ecosystem functions, which usually have negative socioeconomic impacts (examples are given in TABLE 1 and Supplementary information). In a systematic 

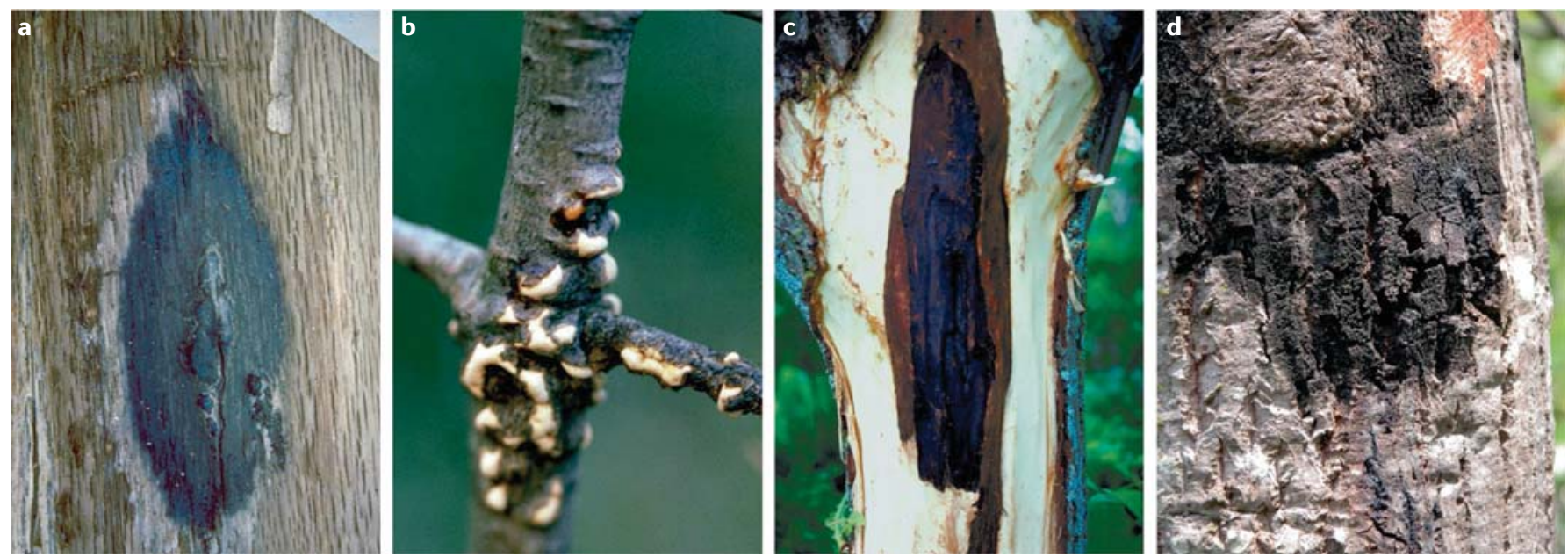

Fig. 1 | Examples of invasive microorganisms that cause tree diseases. a | The fungus Bretziella fagacearum causes wilt in oak trees; the image shows fruiting bodies. b | The fungus Cronartium ribicola causes white pine blister rust; the image shows fruiting bodies on a young pine tree. $\mathbf{c | T h e}$ fungus Sirococcus clavigignenti-juglandacearum causes canker of butternut trees. $\mathbf{d}$ | Phytophthora cinnamomi causes canker and root rot in an oak tree. All pictures reproduced with permission from Bugwood.org: part a courtesy of T. W. Bretz, USDA Forest Service; part b courtesy of USDA Forest Service; part c courtesy of R. L. Anderson, USDA Forest Service; and part d courtesy of J. O'Brien, USDA Forest Service.

literature search (Supplementary information), we identified 85 invasive microorganisms in terrestrial ecosystems. More than two thirds of these invasive microorganisms were pathogens, and of these many were plant-pathogenic fungi and oomycetes (TABLE 1; Supplementary information). It is likely that the higher number of pathogenic microorganisms observed in the microbial invasion literature is due to greater research interest focused on managing pathogenic invasive microorganisms. Moreover, the impacts of non-pathogenic alien microorganisms are relatively difficult to detect compared with those of pathogenic alien microorganisms. In this Review, we provide an overview of the invasion process of both pathogenic and non-pathogenic microorganisms and of their impacts and implications, mainly with examples from terrestrial ecosystems. In doing so, we highlight some of the important gaps in microbial invasion research and suggest potential research avenues and opportunities for integration of different approaches and fields.

\section{The microbial invasion process}

Our current understanding of the invasion process mainly relies on examples from plants and animals ${ }^{18-20}$. Broadly, invasion consists of four stages, starting from the transport of the alien species outside its geographic boundary by human activities, such as intercontinental transport and trade. The alien species is then introduced, intentionally or unintentionally, into a new environment, which could lead to subsequent establishment and spread of the species $^{13}$ (FIG. 2). Importantly, these stages are not discrete but rather occur in a continuum, although different biotic and abiotic barriers apply to each stage $e^{13}$. Microorganisms face the same broad categories of barriers as macroorganisms, although the exact nature of these barriers and the ways to overcome them might differ. For example, whereas most plants and animals have been introduced intentionally (for example, release of lantana plants (Lantana camara) or domestic cats $($ Felis catus $))^{21}$, microorganisms are often introduced non-intentionally, such as mycorrhizal fungi together with their host plants ${ }^{22}$. However, other factors, such as climatic suitability, competition and predation, likely apply to both microorganisms and macroorganisms ${ }^{23}$. Our understanding of the microbial invasion process has mainly been advanced by three non-mutually exclusive research areas and methods: co-invasion of alien macroorganisms and microorganisms (both pathogenic and non-pathogenic), invasion by pathogenic microorganisms that are known to cause severe plant and animal diseases, and invasion of model microorganisms in experimental microcosms.

Co-invasion of alien macroorganisms and microorganisms. Microorganisms that form symbioses (both beneficial and harmful ones) with plants and animals are likely introduced in the new environment together with their symbiotic partners. Several introduced alien plants and their associated microorganisms are instrumental for each other's success in the new environment ${ }^{24,25}$; for example, several mycorrhizal fungi are non-intentionally introduced in a new range together with their host plants ${ }^{26}$. The invasive tree Pinus contorta in New Zealand harbours 93\% ectomycorrhizal fungi of alien origin and the remaining $7 \%$ are native generalist fungi ${ }^{22}$. These mutualistic associations between an alien tree and alien fungi promoted the establishment of both in the new environment ${ }^{22}$, indicating strong and specific symbiosis. Although the co-invasion of animals and associated microorganisms has mainly received attention in disease ecology ${ }^{17}$, such as the co-invasion of the chytrid fungus and American bullfrog (Lithobates catesbeianus) ${ }^{27}$, a recent study showed that forest birds can also transport mycorrhizal fungal 
Table 1 | Key pathogenic invasive microorganisms

\begin{tabular}{|c|c|c|c|c|c|}
\hline Species & $\begin{array}{l}\text { Disease and affected } \\
\text { host(s) }\end{array}$ & $\begin{array}{l}\text { Origin and } \\
\text { geographic range }\end{array}$ & Invasion strategies & Impacts & Refs \\
\hline \multicolumn{6}{|l|}{ Oomycetes } \\
\hline $\begin{array}{l}\text { Phytophthora } \\
\text { ramorum }\end{array}$ & $\begin{array}{l}\text { Sudden oak death; } \\
\text { many trees and shrubs }\end{array}$ & $\begin{array}{l}\text { Asia (low certainty); } \\
\text { Europe, North } \\
\text { America and Asia }\end{array}$ & $\begin{array}{l}\text { Dispersal through air and water } \\
\text { and high strain variability; mostly } \\
\text { asexual reproduction, but sexual } \\
\text { reproduction of different mating } \\
\text { types possible }\end{array}$ & $\begin{array}{l}\text { Owing to wide host range, many } \\
\text { native species and their herbivores } \\
\text { (and pollinators) are threatened }\end{array}$ & 107,108 \\
\hline $\begin{array}{l}\text { Phytophthora } \\
\text { cinnamomi }\end{array}$ & $\begin{array}{l}\text { Root rot; more than } \\
5,000 \text { host species, } \\
\text { especially shrubs and } \\
\text { trees in Australia }\end{array}$ & $\begin{array}{l}\text { South-East Asia } \\
\text { (high certainty); } \\
\text { global }\end{array}$ & Dispersal through soil and plants & $\begin{array}{l}\text { Owing to wide host range, } \\
\text { ecological changes in vegetation } \\
\text { and herbivores potentially } \\
\text { affecting the entire food web. } \\
\text { Many food crops and other } \\
\text { cash plants are affected, such } \\
\text { as avocado, pineapple and } \\
\text { eucalyptus }\end{array}$ & 109 \\
\hline Phytophthora alni & $\begin{array}{l}\text { Phytophthora disease } \\
\text { of alders; Alnus spp. }\end{array}$ & $\begin{array}{l}\text { Europe (high } \\
\text { certainty); Europe } \\
\text { and North America }\end{array}$ & $\begin{array}{l}\text { Dispersal mainly through water bodies } \\
\text { such as rivers. Both sexual and asexual } \\
\text { reproduction; infections favoured by } \\
\text { higher temperatures }\end{array}$ & $\begin{array}{l}\text { Alterations of ecological } \\
\text { communities in Alnus-dominated } \\
\text { forests mainly in riparian } \\
\text { woodlands }\end{array}$ & 111 \\
\hline \multicolumn{6}{|l|}{ Fungi } \\
\hline $\begin{array}{l}\text { Cronartium } \\
\text { ribicola }\end{array}$ & $\begin{array}{l}\text { White pine blister rust; } \\
\text { mostly Pinus and Ribes } \\
\text { spp.; most threatened } \\
\text { Pinus albicaulis }\end{array}$ & $\begin{array}{l}\text { Central-east Eurasia } \\
\text { (moderate certainty); } \\
\text { Europe, North } \\
\text { America and Asia }\end{array}$ & $\begin{array}{l}\text { Produces five spore types; long- } \\
\text { distance dispersal possible through } \\
\text { air }\end{array}$ & $\begin{array}{l}\text { Reduces pine tree dominance in } \\
\text { forests. Associated with major } \\
\text { losses of pine trees in North } \\
\text { America }\end{array}$ & 112,113 \\
\hline $\begin{array}{l}\text { Hymenoscyphus } \\
\text { fraxineus } \\
\text { (also known as } \\
\text { Hymenoscyphus } \\
\text { pseudoalbidus) }\end{array}$ & $\begin{array}{l}\text { Ash dieback; mostly } \\
\text { Fraxinus spp.; } \\
\text { F. excelsior and } \\
\text { F. angustifolia } \\
\text { susceptible }\end{array}$ & $\begin{array}{l}\text { Asia (intermediate } \\
\text { certainty); Europe, } \\
\text { Asia and North Africa }\end{array}$ & $\begin{array}{l}\text { Spread mainly by infected saplings, } \\
\text { locally through air }\end{array}$ & $\begin{array}{l}\text { Younger trees are often more } \\
\text { vulnerable and can thus negatively } \\
\text { affect forest regeneration. Nursery } \\
\text { sectors are heavily affected }\end{array}$ & 114,115 \\
\hline $\begin{array}{l}\text { Cryphonectria } \\
\text { parasitica }\end{array}$ & $\begin{array}{l}\text { Chestnut blight; mainly } \\
\text { Castanea spp. and } \\
\text { Quercus spp. }\end{array}$ & $\begin{array}{l}\text { Asia (high certainty); } \\
\text { Europe, North } \\
\text { America and Asia }\end{array}$ & $\begin{array}{l}\text { Airborne, spread mainly by } \\
\text { animal vectors }\end{array}$ & $\begin{array}{l}\text { Shifts in species dominance } \\
\text { in forests. Economic losses } \\
\text { associated with death of } \\
\text { chestnut trees }\end{array}$ & 33,116 \\
\hline $\begin{array}{l}\text { Sirococcus } \\
\text { clavigignenti- } \\
\text { juglandacearum } \\
\text { (also known as } \\
\text { Ophiognomonia } \\
\text { clavigignenti- } \\
\text { juglandacearum) }\end{array}$ & $\begin{array}{l}\text { Butternut canker; } \\
\text { Juglans spp. }\end{array}$ & $\begin{array}{l}\text { Asia or South America } \\
\text { (low certainty); Asia, } \\
\text { South America and } \\
\text { North America }\end{array}$ & $\begin{array}{l}\text { Spread by insect vectors and seeds } \\
\text { and locally through wind and water; } \\
\text { very aggressive }\end{array}$ & $\begin{array}{l}\text { Reduction of nuts that represent } \\
\text { a major food source for wildlife. } \\
\text { Economic losses in walnut } \\
\text { production }\end{array}$ & 117 \\
\hline $\begin{array}{l}\text { Austropuccinia } \\
\text { psidii (also known } \\
\text { as Puccinia psidii) }\end{array}$ & $\begin{array}{l}\text { Myrtle rust; plants in } \\
\text { the Myrtaceae family } \\
\text { (>400 species) }\end{array}$ & $\begin{array}{l}\text { South America } \\
\text { (high certainty); } \\
\text { global, except for } \\
\text { Europe }\end{array}$ & $\begin{array}{l}\text { Wind and rain-assisted dispersal; } \\
\text { movement of infected nursery stock } \\
\text { had an important role in its spread }\end{array}$ & $\begin{array}{l}\text { Damage ranges from minor } \\
\text { leaf spots, branch dieback } \\
\text { and reduced fecundity to tree } \\
\text { death. Destroys eucalyptus and } \\
\text { commercial plants such as guava }\end{array}$ & 118 \\
\hline $\begin{array}{l}\text { Discula } \\
\text { destructiva }\end{array}$ & $\begin{array}{l}\text { Dogwood anthracnose; } \\
\text { Cornus spp. (dogwood } \\
\text { species) }\end{array}$ & $\begin{array}{l}\text { Asia (low certainty); } \\
\text { Asia, Europe and } \\
\text { North America }\end{array}$ & $\begin{array}{l}\text { Infection spreads through petiole of } \\
\text { the host tree to branch and finally to } \\
\text { trunk }\end{array}$ & $\begin{array}{l}\text { Cornus spp. are severely affected, } \\
\text { leading to death and impairing the } \\
\text { ability for regeneration }\end{array}$ & 119 \\
\hline $\begin{array}{l}\text { Raffaelea } \\
\text { lauricola }\end{array}$ & $\begin{array}{l}\text { Laurel wilt; symbionts } \\
\text { of Xyleborus glabratus }\end{array}$ & $\begin{array}{l}\text { Asia (high certainty); } \\
\text { Asia and North } \\
\text { America }\end{array}$ & $\begin{array}{l}\text { Transported mainly by female } \\
\text { ambrosia beetles (X. glabratus), } \\
\text { which construct tunnels and lay } \\
\text { eggs, thereby promoting the } \\
\text { movement of pathogens into } \\
\text { tree vessels }\end{array}$ & $\begin{array}{l}\text { Changes maritime woodlands as } \\
\text { laurels are killed. Avocado plants } \\
\text { are highly susceptible }\end{array}$ & 120 \\
\hline $\begin{array}{l}\text { Bretziella } \\
\text { fagacearum } \\
\text { (also known as } \\
\text { Ceratocystis } \\
\text { fagacearum) }\end{array}$ & $\begin{array}{l}\text { Oak wilt; Quercus spp. } \\
\text { and Castanea spp. }\end{array}$ & $\begin{array}{l}\text { South America } \\
\text { (intermediate } \\
\text { certainty); South } \\
\text { America, North } \\
\text { America and Europe }\end{array}$ & $\begin{array}{l}\text { Introduced by insect vectors } \\
\text { (such as bark beetles) with oak wood } \\
\text { trade; sporulation mats formed } \\
\text { by the pathogen lead to cracks in } \\
\text { oak barks }\end{array}$ & $\begin{array}{l}\text { Quercus-dominated forests } \\
\text { severely damaged; major threat } \\
\text { to oak-based commercial sectors }\end{array}$ & 121 \\
\hline
\end{tabular}


Table 1 (cont.) | Key pathogenic invasive microorganisms

\begin{tabular}{|c|c|c|c|c|c|}
\hline Species & $\begin{array}{l}\text { Disease and affected } \\
\text { host(s) }\end{array}$ & $\begin{array}{l}\text { Origin and } \\
\text { geographic range }\end{array}$ & Invasion strategies & Impacts & Refs \\
\hline \multicolumn{6}{|l|}{ Fungi (cont.) } \\
\hline $\begin{array}{l}\text { Gibberella } \\
\text { circinata } \\
\text { (also known } \\
\text { as Fusarium } \\
\text { circinatum) }\end{array}$ & $\begin{array}{l}\text { Pitch canker; mainly } \\
\text { Pinus spp. }\end{array}$ & $\begin{array}{l}\text { Unknown; global, } \\
\text { except for Australia }\end{array}$ & $\begin{array}{l}\text { Wind (airborne) and insect vectors } \\
\text { are the main dispersal agents; } \\
\text { successful infection requires } \\
\text { adequately moist conditions }\end{array}$ & $\begin{array}{l}\text { Severe cases of pine infections } \\
\text { can potentially shift pine forest to } \\
\text { oak-dominated woodlands }\end{array}$ & 122 \\
\hline $\begin{array}{l}\text { Heterobasidion } \\
\text { annosum }\end{array}$ & $\begin{array}{l}\text { Annosus root rot; } \\
\text { several species from } \\
\text { the Pinaceae family }\end{array}$ & $\begin{array}{l}\text { Europe and } \\
\text { North America } \\
\text { (low certainty); } \\
\text { North America, } \\
\text { Europe, Asia and } \\
\text { Australia }\end{array}$ & $\begin{array}{l}\text { Dispersed by wind, currents and } \\
\text { insect vectors; colonize tree stumps } \\
\text { as saprotroph to enter roots; } \\
\text { symptoms are hard to detect as } \\
\text { mainly root structure changes in } \\
\text { initial stage of infection }\end{array}$ & $\begin{array}{l}\text { Known for creating gaps in } \\
\text { forests by killing host trees, which } \\
\text { changes resource availability, } \\
\text { such as light and moisture, and } \\
\text { affects forest communities }\end{array}$ & 123 \\
\hline $\begin{array}{l}\text { Ophiostoma } \\
\text { novo-ulmi }\end{array}$ & $\begin{array}{l}\text { Dutch elm disease; } \\
\text { Ulmus spp. }\end{array}$ & $\begin{array}{l}\text { Asia (intermediate } \\
\text { certainty); North } \\
\text { America, Europe, Asia } \\
\text { and New Zealand }\end{array}$ & $\begin{array}{l}\text { Bark beetles are one of the main } \\
\text { dispersal agents; also dispersed by } \\
\text { root grafts; infections often kill the } \\
\text { host owing to effective transmission } \\
\text { to the whole tree }\end{array}$ & $\begin{array}{l}\text { Changes forest community } \\
\text { structure mainly in floodplain areas } \\
\text { where elms are more abundant; } \\
\text { more than } 1 \text { billion elm trees have } \\
\text { been killed since the early } 1900 \text { s }\end{array}$ & 124,125 \\
\hline $\begin{array}{l}\text { Ceratocystis } \\
\text { fimbriata }\end{array}$ & $\begin{array}{l}\text { Ceratocystis blight; } \\
\text { diverse plants in several } \\
\text { plant families }\end{array}$ & $\begin{array}{l}\text { North America, } \\
\text { South America } \\
\text { and Asia; global }\end{array}$ & $\begin{array}{l}\text { Pruning wounds of trees are usually } \\
\text { the main entry points and insects } \\
\text { are the main vectors (attracted by } \\
\text { the fruiting smell of the pathogen) }\end{array}$ & $\begin{array}{l}\text { Changes ecosystems especially } \\
\text { in invaded areas; natural systems } \\
\text { not that strongly affected }\end{array}$ & 126 \\
\hline $\begin{array}{l}\text { Mycosphaerella } \\
\text { pini }\end{array}$ & $\begin{array}{l}\text { Dothistroma blight; } \\
\text { several species from } \\
\text { the Pinaceae family }\end{array}$ & Unknown; global & $\begin{array}{l}\text { Rain splashes assist migration; } \\
\text { high humidity is crucial for successful } \\
\text { infection }\end{array}$ & $\begin{array}{l}\text { Pinus-dominated forests undergo } \\
\text { dramatic changes; threatens } \\
\text { wood production from trees, } \\
\text { such as Pinus radiata }\end{array}$ & 127 \\
\hline
\end{tabular}

Spillover effects

The process in which a pathogen of one host infects another host.

Invasibility

The vulnerability of an environment (or a host) to invasion by alien organisms

Virulence

The ability of microorganisms to cause disease in a host. diaspores, which can potentially increase the spread of mycorrhizal fungi ${ }^{28}$. A similar case was reported for alien mammals (wild boar and deer) on an Argentinian island that spread ectomycorrhizal fungi in their faeces, which subsequently promoted the establishment of an alien pine tree (Pseudotsuga menziesii) ${ }^{29}$.

Although most host plants escape from their native pathogens when introduced in a new region ${ }^{30}$, a recent review ${ }^{25}$ argued that even minimal co-invasion of host plants and pathogens can have dramatic negative effects if the pathogens spill over to native plants, as they are naive and not adapted to the novel pathogens. We discuss such spillover effects later.

Invasion of pathogenic alien microorganisms. There are numerous examples of invasions of pathogenic alien microorganisms, several with devastating effects on the recipient ecosystems owing to disease outbreaks in host plants and animals (TABLE 1; Supplementary information). Many of these pathogenic alien microorganisms were introduced unintentionally together with infected (alien) hosts ${ }^{31,32}$. For example, Cryphonectria parasitica, the fungus responsible for chestnut blight disease in North America, was unintentionally but repeatedly introduced with infected chestnut plants from the Japanese island of Honshu to North America in the early twentieth century $^{33,34}$.

Epidemiological factors and host immunity are important determinants of the invasion process of pathogenic alien microorganisms $\mathrm{s}^{35,36}$. Host immunity reduces invasibility by increasing resistance against alien microbial pathogens, whereas the reproductive rate and transmission potential of the pathogen determine its invasiveness $^{37}$. For example, stomatal guard cells in plants can detect surface molecules of pathogenic bacteria, and in response plants close their stomata to prevent pathogen entry $^{38}$. On the other hand, microorganisms have several virulence mechanisms to overcome host immunity ${ }^{39}$. One of the well-studied alien oomycetes, Phytophthora ramorum, expresses a diverse group of proteins as virulence that can damage the immune system of its host plant (for example, oak trees) and cause infection, leading to host death ${ }^{40,41}$. However, whether there is a direct link between virulence and invasiveness for invasion success or failure merits further investigation.

Experimental microbial invasion in microcosms. Studying microbial invasion in experimental microcosms can elucidate which biotic and abiotic factors can constrain or promote the establishment of invading microorganisms in a new environment ${ }^{23}$. A notable example of such studies is the investigation of how the diversity of recipient microbial communities influences the invasion of microorganisms. The classic diversityinvasibility hypothesis (also sometimes referred as the 'biotic resistance hypothesis') proposed for plants and animals predicts that the more diverse the native plants or animals are the fewer invasions of alien plants or animals there will be owing to greater resource utilization in diverse communities and thus less resource availability for alien species ${ }^{42,43}$. In agreement with the diversity-invasibility hypothesis, an experimental study ${ }^{44}$ showed that high diversity of soil bacterial communities can resist the invasion of an Escherichia coli strain. Another microcosm study highlighted that the functional diversity of resident soil bacterial communities mattered more than the bacterial richness in resisting the invasion of an incoming invading Pseudomonas 
Propagule pressure

The initial size of the introduced population of an alien species

in a new environment.

Invasional meltdown

Positive interactions among

alien species leading to their invasion success. fluorescens strain ${ }^{45}$. Both studies emphasized that the ability of resident microbial communities to use available nutrients was a key factor in resisting the invasion of incoming microorganisms. When resources become limiting owing to efficient consumption by native microbial communities as assumed by the diversityinvasibility hypothesis, invading microorganisms might be less likely to succeed. However, such biotic resistance to invasion of highly diverse residents can be overcome by a high propagule pressure of the alien organism $^{46}$, as evidenced by the freshwater invasive alga Prymnesium parvum ${ }^{47}$.

Although experimental microcosm studies have provided important insights into factors important for microbial invasion, most of these studies used model microorganisms instead of known alien microorganisms, potentially because of difficulties in maintaining laboratory cultures of alien microorganisms such as P. ramorum ${ }^{10}$. Nevertheless, field studies have replicated some of the insights from laboratory experiments. For example, forests with more diverse trees can better resist the invasion by $P$. ramorum than forests with less diverse trees $^{48}$ (TABLE 1), confirming the negative diversityinvasibility relationship observed in microcosm studies, although in this example host diversity rather than resident microorganism diversity was evaluated.

\section{Ecological impacts}

Ecological impacts of alien species are often studied at three levels ${ }^{49}$ : impacts on native species, impacts on recipient communities and impacts on ecosystem processes. In general, impacts on native species underlie impacts on ecological communities, and these in turn underlie impacts on ecosystem processes. However, a meta-analysis of invasive plant species ${ }^{49}$ showed that the magnitude and direction of their impacts on the three levels can differ. Whereas the diversity of native plants and animals declined with the invasion of alien plants, communities and ecosystems were rarely negatively

\section{Box $1 \mid$ Alien microorganisms in other systems}

Invasion of alien microorganisms has been studied in several environments other than terrestrial ecosystems. Researchers in medicine and pathology have studied for decades how alien microorganisms enter the human body ${ }^{91}$, although they use a different definition of 'alien microorganism'. Specifically, in these fields invasion involves entry of pathogens into host cells or tissues leading to spread in the human body and disease ${ }^{92}$. Thus, any microbial pathogen that enters a human body is considered alien and is called 'invasive' if it causes disease. Moreover, medically an invasive infection is defined as one that enters a body compartment where usually no (or very few) microorganisms reside and that breaches the body's barrier. Without symptoms this would be harmless translocation, with symptoms an invasive infection ${ }^{93}$. Several human disease-causing microorganisms have also been introduced in new regions ${ }^{94}$. Many such cases highlight the co-invasion of an alien host and an alien microbial pathogen ${ }^{95}$; for example, dengue virus hosted by the Asian tiger mosquito (Aedes albopictus), which was introduced by human activities in most of the continents outside Asia ${ }^{96}$, and Francisella tularensis (which causes tularaemia), which was introduced together with its crayfish vector (Procambarus clarkia) in North America ${ }^{94,97}$. There are many other examples of alien macroorganisms that are vectors of human pathogenic microorganisms ${ }^{98}$. Several alien microorganisms were also identified in aquatic and marine environments $s^{51,99}$, including non-pathogenic ones ${ }^{51}$. Furthermore, the recently compiled GRIIS database provides an extensive list of alien microorganisms across ecosystems (see also Supplementary information). affected ${ }^{49}$. Similarly, invasive terrestrial invertebrates also had different effects at different levels: they reduced the diversity of native animal communities but positively affected the recipient ecosystems by increasing decomposition of leaf litter ${ }^{50}$. In general, as most known alien microorganisms are pathogens $s^{51}$, their impact is expected to be negative at all levels. We poorly understand whether negative effects of non-pathogenic invasive microorganisms at one level propagate negatively or positively to other levels. Next, we discuss the impact of both pathogenic and non-pathogenic invasive microorganisms on the three ecological levels.

Impacts on native species. Several invasive microorganisms infect mainly native plants as their primary host (TABLE 1; Supplementary information). Invasive pathogenic microorganisms tend to severely affect native plants when they can infect multiple organs of the plants or a range of host plants, and when the environmental conditions, such as temperature and humidity, promote infection and virulence ${ }^{52}$. Some of the well-known invasive microorganisms are restricted to single hosts, such as Discula destructiva, which mainly infects dogwood trees (TABLE 1), but some, such as members of the genus Phytophthora, can infect various plant groups, including trees of Quercus and Pinus species and several species of shrubs. Invasive pathogens with a broad host range and high virulence are often the most lethal ${ }^{53}$. For example, Phytophthora cinnamomi (FIG. 1; TABLE 1) has infected more than 5,000 woody plant species in more than 70 countries, with severe effects such as dieback of forests where alien, such as in Australia $^{5,55}$. We have summarized the ecological and economic impacts of some of the well-known pathogenic invasive microorganisms of terrestrial environments in TABLE 1.

Some alien pathogenic microorganisms can differentially affect alien and native plants. For example, a group of pathogenic fungi associated with the invasive alien plant Vincetoxicum rossicum in North America reduced the biomass of a co-occurring native plant, Solidago canadensis, but positively affected the alien V. rossicum $^{56}$. Although such examples are rare, we speculate that invasive pathogenic microorganisms can trigger invasional meltdown ${ }^{57}$ by causing greater damage to native plants than to alien plants, thereby facilitating the invasion. Moreover, we propose that invasional meltdown is more likely when alien plants and alien microorganisms co-invade an environment ${ }^{25}$.

Animals often facilitate the spread of alien microorganisms either as vectors or as reservoirs ${ }^{9,58}$ (TABLE 1). Some invasive pathogenic fungi can influence the behaviour of their animal vectors, with far-reaching consequences for plants and ecosystems. For example, the invasive fungus Leptographium procerum in China increases the aggression of its insect vectors, such as the red turpentine beetle (also invasive in China), which has killed millions of native Pinus trees in central China ${ }^{59}$. Although evidence of the beetle and the fungus arriving in China together is not yet clear, the fungus very likely adopted the beetle as its vector in China, with serious implications for the tree industry ${ }^{59}$. 
Dilution

Reduction in disease risk due to a greater diversity of hosts.

Evenness

A measure of biological

diversity based on the

quantification of how equal

the community is in terms of

abundance across species.
The impact of invasive microorganisms on animals is not limited to behavioural changes or using them as vectors; their survival is also impacted. An important example of this is white-nose syndrome in North American bats, which is caused by an invasive fungal pathogen introduced from Eurasia, Pseudogymnoascus destructans ${ }^{60}$. White-nose syndrome has killed more than 1 million bats belonging to nine different species ${ }^{60,61}$. North American bats are susceptible to $P$. destructans in their hibernating stage (low body temperature favours fungal infection), whereas Eurasian bats are less susceptible, presumably owing to their long co-evolutionary history with the fungus ${ }^{62}$.

Non-pathogenic alien microorganisms that require their hosts to survive, such as arbuscular mycorrhizal fungi and nitrogen-fixing bacteria, can influence native plant species by disrupting their associations with native, non-pathogenic microorganisms ${ }^{25}$. For example, co-invasion of a legume species and nitrogen-fixing bacteria in coastal dunes in Portugal contributed to the success of the alien species and also disrupted the mutualism between native legumes and native nitrogen-fixing bacteria $^{63}$. In a recent study, the success of an invasive tree, Acacia dealbata, in South Africa was linked to its unique rhizosphere microbiome mostly containing nitrogen-fixing bacteria, which likely co-invaded the environment with $A$. dealbata from Australia ${ }^{64}$. Another example of co-invasion of hosts and nonpathogenic microorganisms is alien Pinus trees and their alien ectomycorrhizal fungi in New Zealand ${ }^{22}$. The effects of alien arbuscular mycorrhizal fungi on native plant performance (measured as biomass) were generally neutral, whereas the response of native plants to native arbuscular mycorrhizal fungi was more positive,

\section{Box 2 | Climate change and microbial invasion}

Alien species in a new region are affected by local environmental conditions, which are often novel and might constrain alien persistence ${ }^{12,13,36}$. A large fraction of alien species fail at this stage. Climate change might result in a more favourable environment for an alien organism, irrespective of whether it is a macroorganism or a microorganism, and thereby might increase its probability to reach a persistent population and to become invasive ${ }^{6,39}$. It has been suggested that warming can increase over-winter survival of several pathogenic microorganisms ${ }^{100}$. Indeed, the success of some of the very wellknown alien microbial pathogens, such as the fungus causing white-nose syndromes in bats, depends on higher winter temperature ${ }^{101}$. Theoretical studies have also supported that even a moderate increase in temperature increases infection rates of pathogens in host populations ${ }^{102}$. Furthermore, when climate warming increases temperatures above the optimal temperatures of hosts, this might increase their susceptibility to infectious diseases, as shown for amphibian infections by the invasive fungal pathogen Batrachochytrium dendrobatidis ${ }^{103,104}$.

Global climate change will also affect the co-invasion of alien macroorganisms and microorganisms. For example, higher temperatures might favour an alien host plant in a new range and thereby also alien microbial pathogens. In such cases, the rates of spillover and disease could rise and negatively affect native communities. However, the success of several alien pathogenic microorganisms has been relatively independent of climate change when compared with other alien groups such as invertebrates in the United Kingdom ${ }^{6}$. When alien invertebrates are vectors of alien pathogenic microorganisms, we can expect a greater risk of pathogen outbreaks. Such results further emphasize the importance of surveillance of alien invertebrates that can potentially be the vector or the reservoir of alien pathogenic microorganisms. Moreover, with an increasing frequency of extreme events such as heat waves and prolonged drought periods, future research should prioritize how the fate of alien microorganisms in these conditions depends on the responses of alien and native hosts. although variable ${ }^{65}$. These examples suggest that invasional meltdown can also occur with non-pathogenic microorganisms.

Impacts on native communities. When invasive pathogens infect dominant community members, they spread faster and have greater negative effects on the native communities and ecosystem processes than when they infect rare members of the community ${ }^{35,66}$. In such cases, the probability of spillover of pathogens from infected hosts to other hosts is more likely simply due to a greater pathogen population, and thus a higher propagule pressure ${ }^{66}$. The strength of community-level consequences of invasive pathogens depends on the degree of spillover ${ }^{66,67}$. Spillover of pathogens is more likely between phylogenetically related hosts and between abundant hosts ${ }^{68}$. Several microbial traits, such as fast growth and efficient dispersal, could also be important for spillover and invasion success ${ }^{23,51}$. Furthermore, considering the traits of alien microorganisms together with the traits of their potential host is even more informative; for example, a host that can disperse widely is expected to amplify the success of a fast-growing alien microorganism ${ }^{66}$. At the same time, the characteristics of recipient ecosystems are key determinants of spillover. Forests with diverse trees can cause dilution of the invasive oomycete $P$. ramorum and thereby limit its negative effects ${ }^{48}$.

Empirical evidence of how a successful alien microorganism affects the diversity of native microbial communities is still limited and has come mainly from microcosm studies. A recent experiment with artificial growth medium showed that alien microorganisms that have higher growth rates and fitness than native microorganisms affect native microbial communities more strongly (by decreasing evenness) than alien microorganisms with lower growth rates than native microorganisms ${ }^{69}$. Other laboratory studies have highlighted that the invasion success and impact of alien microorganisms are usually highest when they are functionally and phylogenetically dissimilar to those from native microbial communities ${ }^{45,70}$.

Community-level consequences of microbial invasions also depend on how alien microorganisms interact with native microorganisms ${ }^{52}$. Despite the increasing examples of the impacts of invasive microorganisms on their hosts and recipient communities, we still have little information on how an invasive microorganism may differ in its traits from the native microorganisms with which it is going to interact (FIG. 2), and whether this has anything to do with its success or failure. This deficit is true for both pathogenic and non-pathogenic microorganisms ${ }^{8}$. As shown by research in plant invasion ${ }^{71}$, such understanding of differences in traits between alien species and native species is crucial for improving our predictions for the impact of alien invaders at all levels. Experimental studies have shown that the establishment of an alien microorganism is often constrained by the biotic environment, and in particular by the immediate competitors and predators ${ }^{23}$. Indeed, previous reviews have highlighted the importance of horizontal interactions (with competitors such as native microorganisms) 


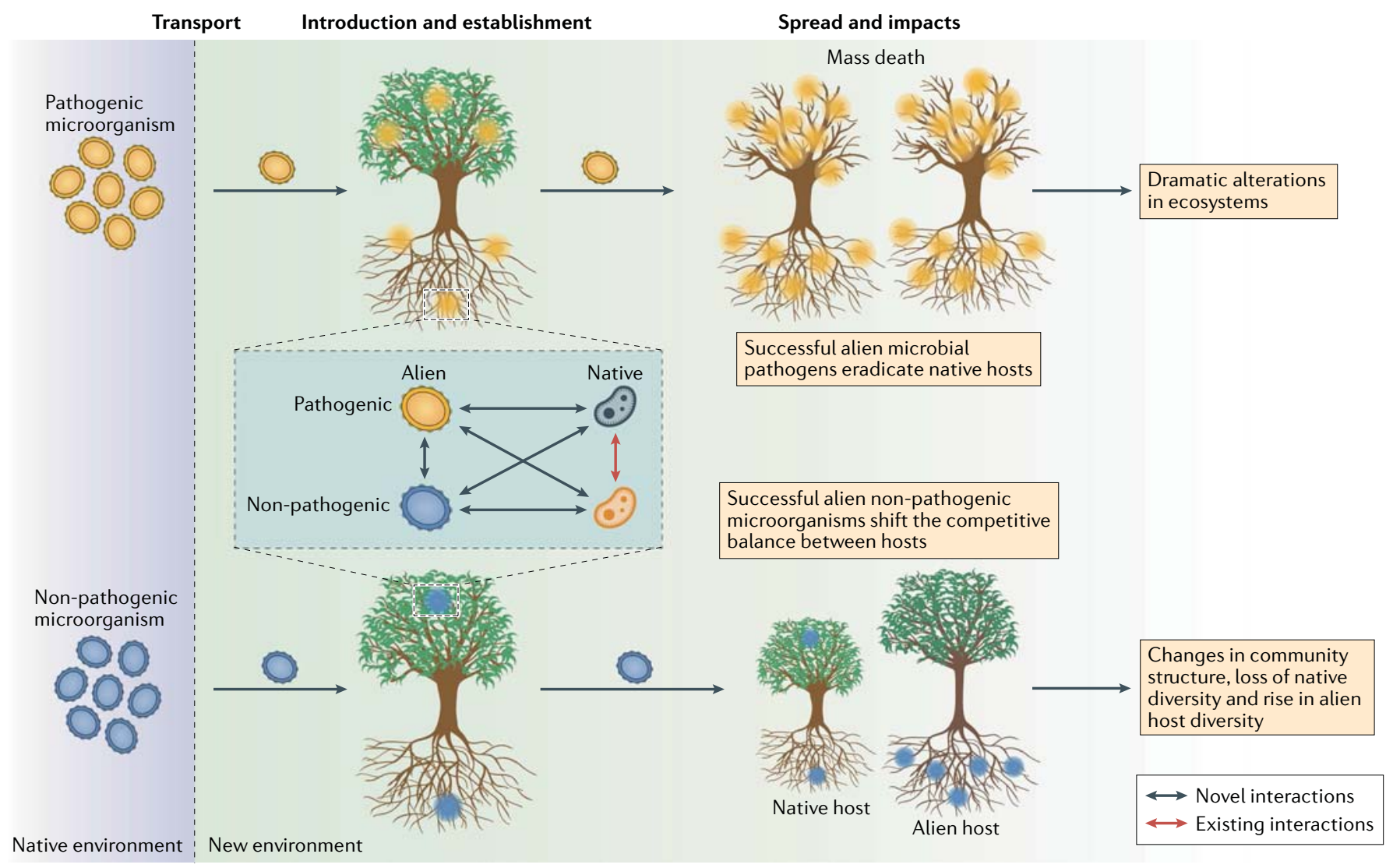

Fig. 2 | The microbial invasion process and potential impacts. As microorganisms are transported outside their geographic range and introduced in the new environment, they start colonizing new hosts or spill over from their native hosts with which they may have been introduced. Subsequently, their establishment involves a suite of interactions, for example with native microorganisms. Multiple infection points or foci on hosts can exist, the frequency of which may differ between pathogenic and non-pathogenic alien microorganisms. The impacts of alien microorganisms become noticeable when they start to spread. Non-pathogenic microorganisms might cause shifts in host community structure, for example favouring alien plant species. All these processes may vary with space and time.

Adaptive immunity

The acquired ability of an infected host to recognize and destroy the pathogen.

Community modules Configurations of species interactions within a community, such as predator-prey or host-pathogen pairs. and vertical interactions (with primary consumers) in determining the invasion success and thereby the consequences for the resident communities ${ }^{23,24,52}$.

Impacts on ecosystem processes. The decline of host plants and animals owing to infection by invasive alien microorganisms could lead to a decline in ecosystem processes, such as biomass production and decomposition. Although studies on plant and animal invasions show invasion-induced changes in ecosystem processes, meta-analyses have failed to detect a consistent negative effect on ecosystem processes ${ }^{49,50,72}$. Potential explanations are that the invasive organisms took over the functions performed by native species or that there is a delay before effects at the ecosystem level become detectable. Thus, whether the commonly observed negative impact on species and/or communities by alien microorganisms also leads to a decline in ecosystem processes requires stronger scrutiny given the lack of studies linking host-level impacts to ecosystem levels. Indeed, when pathogenic invasive microorganisms cause forest dieback or the extinction of animal populations, one could expect such strong negative impacts at the species and/or community level to propagate to ecosystem processes. Although less conspicuous than pathogens, the introduction of non-pathogenic microorganisms such as nitrogen-fixing bacteria with their host plants can dramatically affect the nitrogen cycle in the recipient ecosystems, as has been shown for the invasion of a shrub (Myrica faya) and its nitrogen-fixing symbionts belonging to the genus Frankia on Hawaii ${ }^{73}$.

We suggest that a better understanding of ecosystem responses can be achieved when changes in host behaviour and population dynamics can be linked to a set of ecosystem processes. For example, when a host plant is infected, it defends itself against the alien pathogen through its adaptive immunity ${ }^{74}$. Changes in host defences might affect ecosystem processes such as decomposition of litter from that host plant, and this could link host responses to changes in ecosystem-level processes.

Linking spillover with the impacts of microbial invasion. Studying spillover of alien pathogens is important for understanding their spread and the impact on multiple hosts ${ }^{66}$. We propose that community modules ${ }^{75}$ can improve our insight into how spillover may impact communities and subsequently ecosystem processes. For example, spillover at the same trophic level (horizonal 


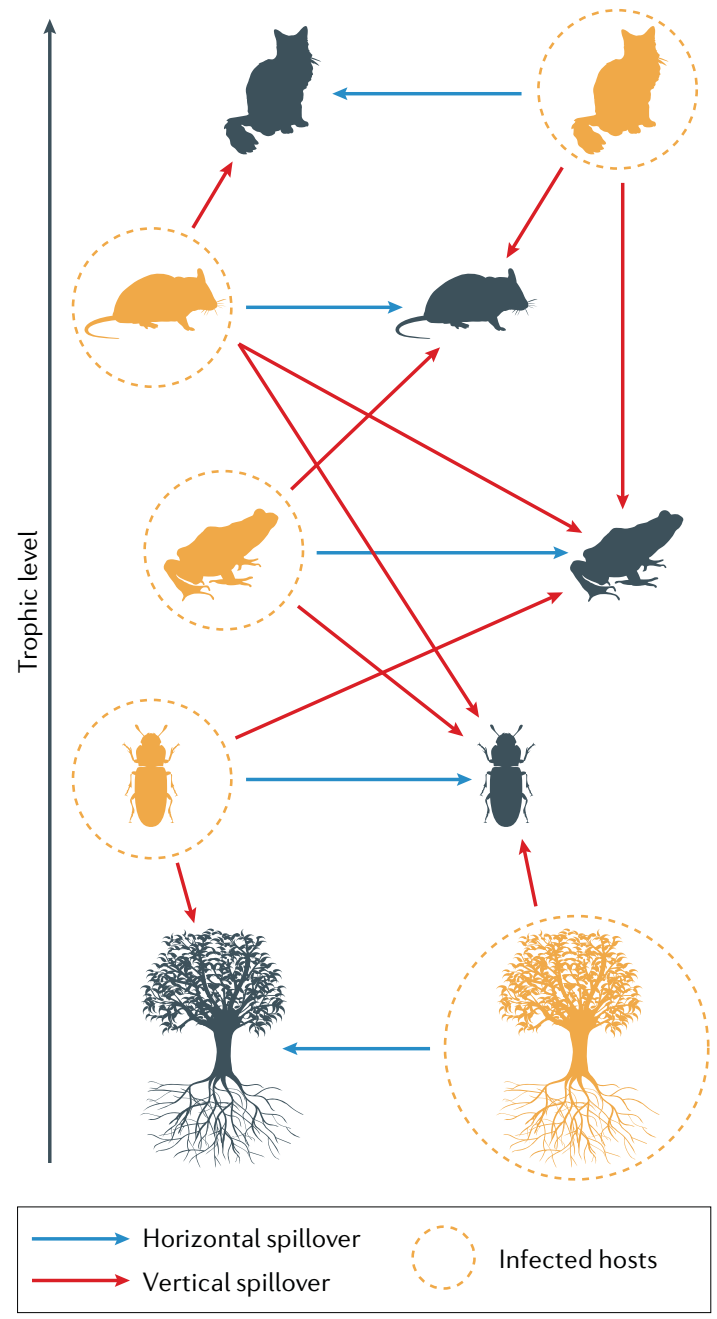

Fig. 3 | Pathways of spillover of alien pathogenic microorganisms. Horizontal spillover occurs when an infected host transfers an alien microbial pathogen to another species at the same trophic level (for example, an infected host plant infecting another host plant). When an infected host is a resource or a consumer species, its interaction with the consumer or resource can facilitate the transfer of alien microbial pathogens, leading to vertical spillover (for example, a healthy predator becomes infected after feeding on infected prey). Both horizonal and vertical spillover can simultaneously occur in networks when multiple infected hosts are both consumers and resources and interact with several members of the community.

spillover) may impact communities differently than spillover across trophic levels (vertical spillover) (FIG. 3). For a better community and ecosystem perspective of alien microorganism impacts, considering both forms of spillover is crucial. The use of networks ${ }^{76}$ in ecology and microbiology has contributed substantially to understanding of both horizontal and vertical interactions among species ${ }^{77}$ and has the potential to determine connectivity between different compartments in ecosystems $^{78}$. We suggest that network approaches, because they can account for both horizontal and vertical spillover, can help us understand the impact of alien microorganisms from a host to a community and ecosystem.
For example, network models can integrate consumers and resources, as often done either in a correlative way or with feeding links when those relationships are known ${ }^{77,79}$. Additionally, by indicating which hosts or consumers are already infected in the network (FIG. 3), we will be better equipped to understand the potential trajectories of spillover. We thus need long-term programmes to monitor and understand the dynamics of pathogen spillover in communities and impacts on ecosystems.

Management and policy implications. Management of alien species has been one of the main priorities of nature conservation and environmental protection agencies (including agricultural agencies and those responsible for providing permits at the entry points of countries) and is a major motivation for research in invasion biology. The Convention on Biological Diversity has called for global collaborative efforts to mitigate the impacts of alien species on native biodiversity and ecosystems ${ }^{80}$. A recent summary for policymakers by the Intergovernmental Science-Policy Platform on Biodiversity and Ecosystem Services has further highlighted that the invasion of alien species is a major threat to native biodiversity and has recommended globally coordinated mitigation approaches ${ }^{81}$. Among key recommendations for national and international policies for microbial invasion mitigations, a recent publication ${ }^{82}$ stressed the need for long-term monitoring and surveillance of host and vector species when they are introduced in a new region. This measure is crucial given that most alien pathogenic microorganisms remain unnoticed for a long time and erupt with sudden outbreaks ${ }^{36}$, such as sudden oak death caused by $P$. ramorum, which takes many months to several years from early infection to causing tree death ${ }^{83}$. Long-term vector surveillance is also important because some alien vectors, such as forest insects, become more damaging to trees when they co-invade an environment with their symbiotic fungi that are pathogenic to plants than when they invade the environment alone ${ }^{84}$.

Global efforts in mitigating emerging infectious diseases in wildlife are gaining greater attention ${ }^{7,39}$. The Food and Agriculture Organization of the United Nations has mandated its more than 180 member states to report plant pests and diseases to the International Plant Protection Convention. The efficacy of such global efforts will increase with greater data sharing among member countries, promoting citizen science and supporting long-term infrastructure for invasion research with emphasis on interactions among alien microorganisms, alien macroorganisms and native species ${ }^{85}$. Moreover, microbial invasion research encompassing both the invasion process and subsequent impacts will be crucial for policy and management (BOX 3).

\section{Outlook}

Invasive microorganisms continue to pose serious threats to native biodiversity and ecosystem functioning and yet they represent one of the most elusive forms of invasions (FIG. 2). That is, invasive microorganisms 


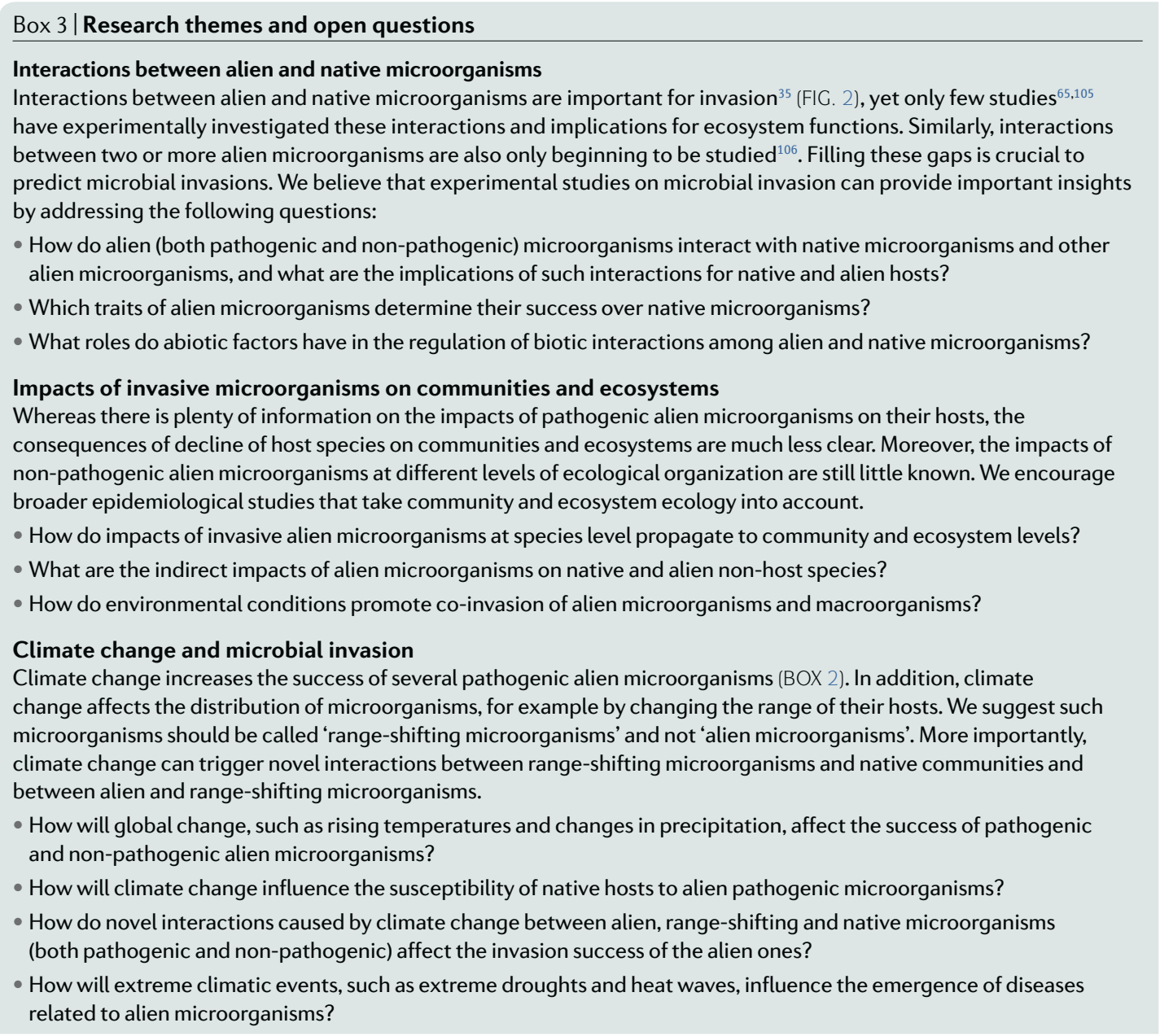

remain, especially compared with plants and animals, difficult to detect and study. However, recent advances in molecular DNA- and RNA-based techniques, including quantitative PCR, (long-read) amplicon sequencing ${ }^{86}$, metagenomics and metatranscriptomics, have greatly advanced our knowledge of known and previously unknown microorganisms, including invasive taxa ${ }^{87}$. These techniques might become routine for tracing invasive microorganisms ${ }^{88}$. We further advocate multidisciplinary approaches to advance microbial invasion research (BOX 3).

As discussed, despite overlapping themes in subfields of microbial invasion research, there is a need for increased synthesis and collaboration. The number of observational studies of invasive pathogenic microorganisms is growing, but more work is needed to link them to the mechanistic insights from microcosm invasion studies. For example, we still know little about the applicability of ecological hypotheses on invasion mechanisms (such as diversity-invasibility relationship, propagule pressure and invasional meltdown $)^{89}$, which are often tested by microcosm studies ${ }^{23}$, to pathogenic alien microorganisms. Microcosm studies, on the other hand, have rarely used the vast knowledge generated by pathology and epidemiological studies of pathogenic alien microorganisms ${ }^{90}$. We identify three research areas (interactions, impact and global change) that might advance integration in microbial invasion research, and accordingly, we propose several questions to address (BOX 3).

The emergence of invasive microbial pathogens was recently classified as one of the most pressing issues for the next two decades 7 . We concur with this assessment, and importantly argue that our ability to manage the emergence of invasive microbial pathogens depends on mechanistic research, long-term monitoring programmes, and regional and global coordinated policies of invasion control and disease management. Furthermore, we argue that the understanding of the microbial invasion process and the impacts at any scale will improve when we consider interactions between alien pathogenic and non-pathogenic microorganisms and native organisms (BOX 3; FIG. 2).

Predicting the invasion of macroorganisms is challenging, and predicting invasions of microorganisms is even more challenging as they usually become noticeable only when they affect other organisms. However, with the advancement of molecular techniques, early detection of alien microorganisms is becoming feasible. In the next two decades, molecular techniques together with experimental approaches are likely to clarify the causes and consequences of microbial invasion. 
1. Chapman, D. Purse B. V Roy, H. E \& Bullock, J. M. Global trade networks determine the distribution of invasive non-native species. Glob. Ecol. Biogeogr. 26, 907-917 (2017).

2. Sikes, B. A. et al. Import volumes and biosecurity interventions shape the arrival rate of fungal pathogens. PLOS Biol. 16, e2006025 (2018).

3. Weiss, $\mathrm{H}$. et al. The airplane cabin microbiome Microb. Ecol. 77, 87-95 (2018)

4. Santini, A., Liebhold, A., Migliorini, D. \& Woodward, S Tracing the role of human civilization in the globalization of plant pathogens. ISME J. 12, 647-652 (2018).

5. Bebber, D. P., Ramotowski, M. A. T. \& Gurr, S. J. Crop pests and pathogens move polewards in a warming world Nat Clim Change 3, 985-988 (2013).

6. Hulme, P. E. Climate change and biological invasions: evidence, expectations, and response options. Biol. Rev. 92, 1297-1313 (2017).

7. Ricciardi, A. et al. Invasion science: a horizon scan of emerging challenges and opportunities. Trends Ecol. Evol. 32, 464-474 (2017).

8. Gladieux, P. et al. The population biology of fungal invasions. Mol. Ecol. 24, 1969-1986 (2015).

9. Desprez-Loustau, M. L. et al. The fungal dimension of biological invasions. Trends Ecol. Evol. 22, 472-480 (2007).

This review is one of the first to highlight the potential invasion mechanisms and impacts of both pathogenic and non-pathogenic fung

10. Judelson, H. S. \& Blanco, F. A. The spores of Phytophthora: weapons of the plant destroyer. Nat. Rev. Microbiol. 3, 47-58 (2005) This Review provides an overview of several pathogenesis strategies of Phytophthora.

11. Scheele, B. C. et al. Amphibian fungal panzootic causes catastrophic and ongoing loss of biodiversity. Science 363, 1459-1463 (2019).

12. Richardson, D. M. et al. Naturalization and invasion of alien plants: concepts and definitions. Divers. Distrib. 6, 93-107 (2000).

13. Blackburn, T. M. et al. A proposed unified framework for biological invasions. Trends Ecol. Evol. 26 333-339 (2011)

14. Essl, F. et al. Which taxa are alien? Criteria, applications, and uncertainties. Bioscience 68 496-509 (2018).

15. Convention on Biological Diversity. COP 5 decision V/8 alien species that threaten ecosystems, habitats or species. CBD https://www.cbd.int/decision/cop/ default.shtml?id=7150 (2000).

16. Zenni, R. D. \& Nuñez, M. A. The elephant in the room the role of failed invasions in understanding invasion biology. Oikos 122, 801-815 (2013).

17. Daszak, P., Cunningham, A. \& Hyatt, A. Emerging infectious diseases of wildlife - threats to biodiversity and human health. Science 287, 443-449 (2000).

18. Kolar, C. S. \& Lodge, D. M. Progress in invasion biology. Trends Ecol. Evol. 16, 199-204 (2001).

19. van Kleunen, M., Bossdorf, O. \& Dawson, W. The ecology and evolution of alien plants. Annu. Rev. Ecol. Evol. Syst. 49, 25-47 (2018).

20. Jeschke, J. et al. Support for major hypotheses in invasion biology is uneven and declining. NeoBiota 14, 1-20 (2012)

21. Turbelin, A J., Malamud, B. D. \& Francis, R. A. Mapping the global state of invasive alien species: patterns of invasion and policy responses. Glob. Ecol. Biogeogr. 26, 78-92 (2017)

22. Dickie, I., Bolstridge, N., Cooper, J. \& Peltzer, D. Co-invasion by Pinus and its mycorrhizal fungi. New Phytol. 187, 475-484 (2010). This study shows co-invasion of Pinus trees and their associated mycorrhizal fungi in New Zealand.

23. Mallon, C., Van Elsas, J. \& Salles, J. Microbial invasions: the process, patterns, and mechanisms. Trends Microbiol. 23, 719-729 (2015).

24. Van der Putten, W. H., Klironomos, J. N. \& Wardle, D. A Microbial ecology of biological invasions. ISME J. 1 , 28-37 (2007)

25. Dickie, I. A. et al. The emerging science of linked plant-fungal invasions. New Phytol. 215, 1314-1332 (2017).

26. Vellinga, E., Wolfe, B. \& Pringle, A. Global patterns of ectomycorrhizal introductions. New Phytol. 181, 960-973 (2009).

This global analysis provides a list of ectomycorrhizal introductions.

27. Lymbery, A. J., Morine, M., Kanani, H. G., Beatty, S. J. ¿ Morgan, D. L. Co-invaders: the effects of alien parasites on native hosts. Int. J. Parasitol. Parasites Wildl. 3, 171-177 (2014).
28. Correia, M. Heleno, R da Silva, L. P. Costa, J M \& Rodríguez-Echeverría, S. First evidence for the joint dispersal of mycorrhizal fungi and plant diaspores by birds. New Phytol. 222, 1054-1060 (2019).

29. Nuñez, M. A. et al. Exotic mammals disperse exotic fungi that promote invasion by exotic trees. PLOS ONE 8, e66832 (2013)

30. Mitchell, C. \& Torchin, M. Parasites, pathogens, and invasions by plants and animals. Front. Ecol. Environ 2, 183-190 (2004).

31. Amsellem, L. et al. Importance of microorganisms to macroorganisms invasions. Adv. Ecol. Res. 57 99-146 (2017)

32. Banks, N. C., Paini, D. R., Bayliss, K. L. \& Hodda, M. The role of global trade and transport network topology in the human-mediated dispersal of alien species. Ecol. Lett. 18, 188-199 (2015).

33. Dutech, C. et al. The chestnut blight fungus world tour: successive introduction events from diverse origins in an invasive plant fungal pathogen. Mol. Ecol. 21 3931-3946 (2012).

This study reveals that $C$. parasitica became invasive in North America and western Europe owing to multiple introduction events.

34. Rigling, D. \& Prospero, S. Cryphonectria parasitica, the causal agent of chestnut blight: invasion history population biology and disease control. Mol. Plant Pathol. 19, 7-20 (2018).

35. Young, H. S., Parker, I. M., Gilbert, G. S., Sofia Guerra, A. ¿ Nunn, C. L. Introduced species, disease ecology, and biodiversity-disease relationships. Trends Ecol. Evol. 32, 41-54 (2017).

36. Parker, I. \& Gilbert, G. The evolutionary ecology of novel plant-pathogen interactions. Annu. Rev. Ecol. Evol. Syst. 35, 675-700 (2004).

37. Anderson, R. \& May, R. The invasion, persistence and spread of infectious diseases within animal and plant communities. Philos. Trans. R. Soc. Lond. B 314 533-570 (1986)

38. Melotto, M., Underwood, W., Koczan, J., Nomura, K. $\Sigma \mathrm{He}$, S. Y. Plant stomata function in innate immunity against bacterial invasion. Cell 126, 969-980 (2006).

39. Anderson, P. K. et al. Emerging infectious diseases of plants: pathogen pollution, climate change and agrotechnology drivers. Trends Ecol. Evol. 19, 535-544 (2004).

40. Tyler, B. M. et al. Phytophthora genome sequences uncover evolutionary origins and mechanisms of pathogenesis. Science 313, 1261-1266 (2006)

41. Grunwald, N., Goss, E. \& Press, C. Phytophthora ramorum: a pathogen with a remarkably wide host range causing sudden oak death on oaks and ramorum blight on woody ornamentals. Mol. Plant Pathol. 9, 729-740 (2008)

42. Elton, C. The Ecology of Invasions by Animals and Plants (Methuen, 1958)

43. Levine, J. Species diversity and biological invasions relating local process to community pattern. Science 288, 852-854 (2000)

44. van Elsas, J. D. et al. Microbial diversity determines the invasion of soil by a bacterial pathogen. Proc. Nat Acad. Sci. USA 109, 1159-1164 (2012).

45. Eisenhauer, N., Schulz, W., Scheu, S. \& Jousset, A. Niche dimensionality links biodiversity and invasibility of microbial communities. Funct. Ecol. 27, 282-288 (2013)

46. Lockwood, J. L., Cassey, P. \& Blackburn, T. The role of propagule pressure in explaining species invasions. Trends Ecol. Evol. 20, 223-228 (2005).

47. Acosta, F., Zamor, R. M., Najar, F. Z., Roe, B. A \& Hambright, K. D. Dynamics of an experimenta microbial invasion. Proc. Natl Acad. Sci. USA 112 11594-11599 (2015).

48. Haas, S. E., Hooten, M. B., Rizzo, D. M. \& Meentemeyer, R. K. Forest species diversity reduce disease risk in a generalist plant pathogen invasion. Ecol. Lett. 14, 1108-1116 (2011).

This study confirmed diversity-invasibility relationships for a plant pathogen from a field study.

49. Vilà, M. et al. Ecological impacts of invasive alien plants: a meta-analysis of their effects on species communities and ecosystems. Ecol. Lett. 14, 702-708 (2011)

50. Cameron, E. K., Vilà, M. \& Cabeza, M. Global metaanalysis of the impacts of terrestrial invertebrate invaders on species, communities and ecosystems. Glob. Ecol. Biogeogr. 25, 596-606 (2016).

51. Litchman, E. Invisible invaders: non-pathogenic invasive microbes in aquatic and terrestrial ecosystems. Ecol. Lett. 13, 1560-1572 (2010)
52. Brader, G et al. Ecology and genomic insights into plant-pathogenic and plant-nonpathogenic endophytes. Annu. Rev. Phytopathol. 55, 61-83 (2017).

53. Fisher, M. C. et al. Emerging fungal threats to animal, plant and ecosystem health. Nature 484, 186-194 (2012).

54. Jung, T., Colquhoun, I. J. \& Hardy, G. E. S. J. New insights into the survival strategy of the invasive soilborne pathogen Phytophthora cinnamomi in different natural ecosystems in Western Australia. For. Pathol. 43, 266-288 (2013).

55. Hee, W. Y., Torreña, P. S., Blackman, L. M. \& Hardham, A. R. in Phytophthora: A Global Perspective Vol. 2 (ed. Lamour, K.) 124 (CABI, 2013).

56. Day, N. J., Dunfield, K. E. \& Antunes, P. M. Fungi from a non-native invasive plant increase its growth but have different growth effects on native plants. Biol. Invasions 18, 231-243 (2016).

57. Simberloff, D. \& Von Holle, B. Positive interaction of nonindigenous species: invasional meltdown? Biol. Invasions 1, 21-32 (1999).

58. Reisen, W. K. Landscape epidemiology of vector-borne diseases. Annu. Rev. Entomol. 55, 461-483 (2010).

59. Taerum, S. J. et al. Putative origins of the fungus Leptographium procerum. Fungal Biol. 121, 82-94 (2017).

60. Lorch, J. M. et al. Experimental infection of bats with Geomyces destructans causes white-nose syndrome. Nature 480, 376-378 (2011).

61. Warnecke, L. et al. Inoculation of bats with European Geomyces destructans supports the novel pathogen hypothesis for the origin of white-nose syndrome.

62. Zukal, J. et al. White-nose syndrome without borders: Pseudogymnoascus destructans infection tolerated in Europe and Palearctic Asia but not in North America. Sci. Rep. 6, 19829 (2016).

63. Rodrïguez-Echeverría, S. Rhizobial hitchhikers from down under: invasional meltdown in a plant-bacteria mutualism? J. Biogeogr. 37, 1611-1622 (2010). This article reveals invasional meltdown in plant-microorganism interactions.

64. Kamutando, C. N. et al. The functional potential of the rhizospheric microbiome of an invasive tree species, Acacia dealbata. Microb. Ecol. 77, 191-200 (2019).

65. Klironomos, J. Variation in plant response to native and exotic arbuscular mycorrhizal fungi. Ecology 84, 2292-2301 (2003)

This study is one of the first to show differences in plant responses to alien and native arbuscular mycorrhizal fungi.

66. Chalkowski, K., Lepczyk, C. A. \& Zohdy, S. Parasite ecology of invasive species: conceptual framework and new hypotheses. Trends Parasitol. 34, 655-663 (2018).

67. Johnson, P. T. J., De Roode, J. C. \& Fenton, A. Why infectious disease research needs community ecology. Science 349, 1259504 (2015).

68. Parker, I. M. et al. Phylogenetic structure and hos abundance drive disease pressure in communities. Nature 520, 542-544 (2015).

This study shows how community characteristics can influence disease outcomes.

69. Li, S.-P., Tan, J., Yang, X., Ma, C. \& Jiang, L. Niche and fitness differences determine invasion success and impact in laboratory bacterial communities. ISME J. 13, 402-412 (2019).

70. Kinnunen, M., Dechesne, A., Albrechtsen, H.-J. \& Smets, B. F. Stochastic processes govern invasion success in microbial communities when the invader is phylogenetically close to resident bacteria. ISME J. 12, 2748-2756 (2018)

71. Van Kleunen, M. Weber, E. \& Fischer, M. A metaanalysis of trait differences between invasive and non-invasive plant species. Ecol. Lett. 13, 235-245 (2010).

72. McCary, M. A., Mores, R., Farfan, M. A. \& Wise, D. H. Invasive plants have different effects on trophic structure of green and brown food webs in terrestrial ecosystems: a meta-analysis. Ecol. Lett. 19, 328-335 (2016).

73. Vitousek, P. \& Walker, L. Biological invasion by Myrica Faya in Hawaii: plant demography, nitrogen fixation, ecosystem effects. Ecol. Monogr. 59, 247-265 (1989).

74. Spoel, S. H. \& Dong, X. How do plants achieve immunity? Defence without specialized immune cells. Nat. Rev. Immunol. 12, 89-100 (2012).

75. Gilman, S. E., Urban, M. C., Tewksbury, J. Gilchrist, G. W. \& Holt, R. D. A framework for community interactions under climate change. Trends Ecol. Evol. 25, 325-331 (2010). 
76. Newman, M Barbási, A.-L \& Watts, D The Structure and Dynamics of Networks (Princeton Univ. Press, 2011

77. Delmas, E. et al. Analysing ecological networks of species interactions. Biol. Rev. 94, 16-36 (2019)

78. Ramirez, K. S., Geisen, S., Morriën, E., Snoek, B. L. \& van der Putten, W. H. Network analyses can advance above-belowground ecology. Trends Plant Sci. 23 759-768 (2018)

79. Tylianakis, J. M. \& Morris, R. J. Ecological networks across environmental gradients. Annu. Rev. Ecol. Evol. Syst. 48, 25-48 (2017)

80. McGeoch, M. A. et al. Global indicators of biological invasion: species numbers, biodiversity impact and policy responses. Divers. Distrib. 16, 95-108 (2010).

81. Diaz, S. et al. Summary for policymakers of the global assessment report on biodiversity and ecosystem services of the Intergovernmental Science-Policy Platform on Biodiversity and Ecosystem Services (IPBES, 2019)

82. Roy, H. E. et al. Alien pathogens on the horizon: opportunities for predicting their threat to wildlife. Conserv. Lett. 10, 476-483 (2017).

83. Rizzo, D. M. \& Garbelotto, M. Sudden oak death endangering California and Oregon forest ecosystems. Front. Ecol. Environ. 1, 197-204 (2003).

84. Wingfield, M. J. et al. Novel and co-evolved associations between insects and microorganisms as drivers of forest pestilence. Biol. Invasions 18, 1045-1056 (2016).

85. Dunn, A. M. \& Hatcher, M. J. Parasites and biological invasions: parallels, interactions, and control. Trends Parasitol. 31, 189-199 (2015).

86. Tedersoo, L., Tooming-Klunderud, A. \& Anslan, S. Methods PacBio metabarcoding of fungi and other eukaryotes: errors, biases and perspectives. New Phytol. 217, 1370-1385 (2017)

87. Koskella, B., Hall, L. J. \& Metcalf, C. J. E. The microbiome beyond the horizon of ecological and evolutionary theory. Nat. Ecol. Evol. 1, 1606-1615 (2017).

88. Hanlon, S. J. O. et al. Recent Asian origin of chytrid fungi causing global amphibian declines. Science 627 621-627 (2018)

This study uses whole-genome sequencing of chytrid fungi to estimate spatiotemporal origins

89. Jeschke, J. M. General hypotheses in invasion ecology. Divers. Distrib. 20, 1229-1234 (2014).

90. Milgroom, M. Population Biology of Plant Pathogens: Genetics, Ecology and Evolution (The American Phytopathological Society, 2015).

91. Gilligan, C. A. $\&$ van den Bosch, F. Epidemiologica models for invasion and persistence of pathogens. Annu. Rev. Phytopathol. 46, 385-418 (2008).

92. Madigan, M., Bender, K., Buckley, D., Sattley, W. \& Stahl, D. Brock Biology of Microorganisms 15th edn (Pearson Education Limited, 2019).

93. Ribet, D. \& Cossart, P. How bacterial pathogens colonize their hosts and invade deeper tissues. Microbes Infect. 17, 173-183 (2015).

94. Mazza, G., Tricarico, E., Genovesi, P. \& Gherardi, F. Biological invaders are threats to human health an overview. Ethol. Ecol. Evol. 26, 112-129 (2014).

95. Hulme, P. Invasive species challenge the global response to emerging diseases. Trends Parasitol. 30 267-270 (2014)

96. Paupy, C., Delatte, H., Bagny, L., Corbel, V. \& Fontenille, D. Aedes albopictus, an arbovirus vector: from the darkness to the light. Microbes Infect. 11, 1177-1185 (2009)

97. Anda, P. et al. Waterborne outbreak of tularemia associated with crayfish fishing. Emerg. Infect. Dis. 7 , 575-582 (2001)

98. Mazza, G. \& Tricarcio, E. (eds) Invasive Species and Human Health (CABI, 2018).
99. Amalfitano S., Coci, M., Corno G. \& Luna, G. M. A microbial perspective on biological invasions in aquatic ecosystems. Hydrobiologia 746, 13-22 (2014)

100. Harvell, C. et al. Climate warming and disease risks for terrestrial and marine biota. Science 296, 2158-2162 (2002)

101. Verant, M. L., Boyles, J. G., Waldrep, W., Wibbelt, G $\&$ Blehert, D. S. Temperature-dependent growth of Geomyces destructans, the fungus that causes bat White-nose syndrome. PLOS ONE 7, e46280 (2012).

02. O'connor, M. I. \& Bernhardt, J. R. The metabolic theory of ecology and the cost of parasitism. PLOS Biol. 16, e2005628 (2018)

103. Cohen, J. M. et al. The thermal mismatch hypothesis explains host susceptibility to an emerging infectious disease. Ecol. Lett. 20, 184-193 (2017).

104. Clare, F. C. et al. Climate forcing of an emerging pathogenic fungus across a montane multi-host community. Philos. Trans. R. Soc. B 371, 20150454 (2016)

105. Mckinney, L., Thomsen, I., Kjær, E., Bengtsson, S. \& Nielsen, L. Rapid invasion by an aggressive pathogenic fungus (Hymenoscyphus pseudoalbidus) replaces a native decomposer (Hymenoscyphus albidus): a case native decomposer (Hymenoscyphus albidus): a case
of local cryptic extinction? Fungal Ecol. 5, 663-669 (2012).

106. Kozanitas, M., Osmundson, T. W., Linzer, R. \& Garbelotto, M. Interspecific interactions between the sudden oak death pathogen Phytophthora ramorum and two sympatric Phytophthora species in varying ecological conditions. Fungal Ecol. 28 86-96 (2017).

107. Rizzo, D. M., Garbelotto, M. \& Hansen, E. M. Phytophthora ramorum: integrative research and management of an emerging pathogen in California and Oregon forests. Annu. Rev. Phytopathol. 43 309-335 (2005).

108. Grünwald, N. J., Garbelotto, M., Goss, E. M. Heungens, K. \& Prospero, S. Emergence of the sudden oak death pathogen Phytophthora ramorum. Trends Microbiol. 20, 131-138 (2012)

109. Hardham, A. \& Blackman, L. Phytophthora cinnamom Mol. Plant Pathol. 19, 260-285 (2018).

110. Robin, C. et al. Root and aerial infections of Chamaecyparis lawsoniana by Phytophthora lateralis: a new threat for European countries. For. Pathol. 41 417-424 (2011)

111. Thoirain, B., Husson, C. \& Marçais, B. Risk factors for the Phytophthora -induced decline of alder in northeastern France. Phytopathology 97, 99-105 (2007)

112. Zambino, P. J. Biology and pathology of Ribes and their implications for management of white pine blister rust. For Pathol 40, 264-291 (2010).

113. Geils, B. \& Vogler, D. A. in The Future of High-Elevation, Five-Needle White Pines in Western North America: Proceedings of the High Five Symposium (eds Keane, R., Tomback, D., Murray, M. \& Smith, C.) 210-217 (U.S. Department of Agriculture Forest Service, 2011)

14. Kowalski, T. \& Holdenrieder, O. Pathogenicity of Chalara fraxinea. For. Pathol. 39, 1-7 (2009)

115. Cleary, M. et al. Friend or foe? Biological and ecological traits of the European ash dieback pathogen Hymenoscyphus fraxineus in its native pathogen Hymenoscyphus fraxineus in its

116. Anagnostakis, S. L. Chestnut blight: the classical problem of an introduced pathogen. Mycologia 79 23-37 (1987)

117. Broders, K., Boraks, A., Barbison, L., Brown, J. $\&$ Boland, G. J. Recent insights into the pandemic disease butternut canker caused by the invasive pathogen Ophiognomonia clavigignentijuglandacearum. For. Pathol. 45, 1-8 (2015).
118. Carnegie A J et al. Impact of the invasive rust Puccinia psidii (myrtle rust) on native Myrtaceae in natural ecosystems in Australia. Biol. Invasions 18, 127-144 (2016)

119. Carr, D. E. \& Banas, L. E. Dogwood anthracnose (Discula destructiva): effects of and consequences for host (Cornus florida) demography. Am. Midl. Nat. 143, 169-177 (2000)

120. Ploetz, R. C. et al. Responses of avocado to laurel wilt, caused by Raffaelea lauricola. Plant Pathol. 61 801-808 (2012)

121. Juzwik, J., Harrington, T. C., MacDonald, W. L. \& Appel, D. N. The origin of Ceratocystis fagacearum, the oak wilt fungus. Annu. Rev. Phytopathol. 46, 13-26 (2008).

122. Wingfield, M. J. et al. Pitch canker caused by Fusarium circinatum - a growing threat to pine plantations and forests worldwide. Australas. Plant Pathol. 37 319-334 (2008)

123. Garbelotto, M. \& Gonthier, P. Biology, epidemiology, and control of Heterobasidion Species worldwide. Annu. Rev. Phytopathol. 51, 39-59 (2013).

124. Brasier, C. in Genetics of Plant Pathogenic Fung 1st edn Vol. 6 (ed. Sidhu, G. S.) 207-223 (Academic Press, 1988).

125. Comeau, A. M. et al. Functional annotation of the ophiostoma novo-ulmi genome: insights into the phytopathogenicity of the fungal agent of Dutch elm disease. Genome Biol. Evol. 7, 410-430 (2015).

126. Baker, C. J., Harrington, T. C., Krauss, U. \& Alfenas, A. C Genetic variability and host specialization in the Latin American clade of Ceratocystis fimbriata. Phytopathology 93, 1274-1284 (2003).

127. Muir, J. A. \& Cobb, F. W. Infection of radiata and bishop pine by Mycosphaerella pini in California. Can. J. For. Res. 35, 2529-2538 (2005).

\section{Acknowledgements}

The authors thank K. Steinauer (Netherlands Institute of Ecology) for her suggestions on the manuscript. M.P.T. acknowledges funding from the German Research Foundation (TH 2307/1-1). W.H.v.d.P. acknowledges support from ERC Advanced Grants (ERC-ADV 323020, SPECIALS). S.G acknowledges funding from the Netherlands Organization for Scientific Research (016.Veni.181.078). This is publication 6755 of the Netherlands Institute of Ecology.

\section{Author contributions}

M.P.T. and S.G. conceived the initial idea and carried out the systematic literature search. All co-authors provided insights to develop the manuscript. M.P.T. wrote the manuscript with inputs from all co-authors.

\section{Competing interests}

The authors declare no competing interests. 